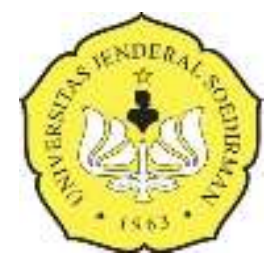

PAJU Volume 1 Nomor 12019

PHYSICAL ACTIVITY JOURNAL

http://jos.unsoed.ac.id/index.php/paju

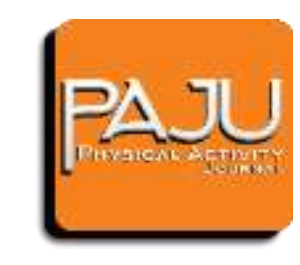

\title{
Pengaruh Permainan Tradisional Terhadap Minat Siswa Dalam Kegiatan Pembelajaran Pendidikan Jasmani, Olahraga, Dan Kesehatan Di Sman 1 Cikembar
}

\author{
Moch Latif1, Faiz Faozi², Rafdlal Saeful Bakhri³, Farid Harja ${ }^{4}$, Arfin Deri Listiandi ${ }^{5}$ \\ 1,2,3,4, Pendidikan Jasmani, Kesehatan dan Rekreasi, STKIP Bina Mutiara Sukabumi, Indonesia \\ 5 Pendidikan Jasmani, Kesehatan dan Rekreasi, Universitas Jenderal Soedirman, Indonesia \\ email: mochammadlatif94@gmail.com 1 , faizfaozi@gmail.com², madal.rafhael@gmail.com³ \\ arfinderilistiandi@gmail.com ${ }^{5}$ \\ DOI: https://doi.org/10.20884/1.paju.2019.1.1.2005
}

\begin{abstract}
Abstrak
Tujuan penelitian: untuk mengetahui pengaruh permainan tradisional terhadap minat siswa dalam pembelajaran pendidikan jasmani di SMA Negeri 1 Cikembar, Kab. Sukabumi. Metode yang digunakan adalah Quasi Experimental (one group pretes-posttest). Populasi dalam penelitian ini adalah siswa-siswi SMA Negeri 1 Cikembar. Sampel dalam penelitian ini adalah siswa-siswi kelas $X$ MIPA 3. Instrumen penelitian yang digunakan adalah tes angket. Teknik analisis data menggunakan paired sample $t$ test dengan $\alpha<0,05$. Hasil penelitian menunjukan terdapat pengaruh permainan tradisional terhadap minat siswa dalam pembelajaran pendidikan jasmani, olahraga dan kesehatan di SMA Negeri Negeri 1 Cikembar.
\end{abstract}

Kata Kunci : Permainan Tradisional, Minat, Pembelajaran Penjas

\section{Abstract}

The purpose of research: to determine the effect of traditional games on student interest in physical education in SMA Negeri 1 Cikembar, Kab. Sukabumi. The method used is Quasi Experimental (one group pretes-posttest). The population in this study are students of SMA Negeri 1 Cikembar. The sample in this research is the students of class X MIPA 3. The research instrument used is questionnaire. Data analysis technique use paired sample t test with $\alpha, 0,05$. The results showed that there were traditional game influences on students' interest in learning physical education, sports and health in Cikembar 1 State Senior High School..

Keywords: Traditional Games, Interest, Peer Learning

\begin{tabular}{|c|c|c|}
\hline Alamat Koresponden & : $\quad$ Prodi PJKR STKIP Bina Mutiara Sukabumi & $\begin{array}{ll}\text { e-ISSN } & : 2686-5807 \\
\text { p-ISSN } & : 2686-5793\end{array}$ \\
\hline $\begin{array}{l}\text { E-mail } \\
\text { No. Telp./Hp }\end{array}$ & : mochammadlatif94@gmail.com & \\
\hline
\end{tabular}




\section{PENDAHULUAN}

Pengoptimalan proses pembelajaran pada mata pelajaran pendidikan jasmani, olahraga, dan kesehatan diharapkan dapat tumbuh dan berkembang nilai-nilai yang bermanfaat bagi perkembangan para siswa SMAN 1 Cikembar. Hal tersebut sejalan dengan penjelasan Yudha Saputra (2008) yang menyatakan bahwa "pendidikan jasmani merupakan pendidikan yang dilakukan melalui aktivitas fisik dan olahraga sebagai media utama untuk mencapai tujuan pendidikan nasional".

Berdasarkan uraian di atas maka pendidikan jasmani mempunyai peranan yang sangat penting dan unik dibandingkan bidang studi lainnya, karena pendidikan jasmani mempunyai peran yang lebih besar dari mata pelajaran lainnya untuk membina dan melatih keterampilan. Hal ini menjadi kelebihan pendidikan jasmani dari pelajaran-pelajaran lainnya. Jika pelajaran lain lebih mementingkan pengembangan intelektual, maka melalui pendidikan jasmani akan terbina aspek -aspek atau ranah-ranah pendidikan jasmani yang menjadi ciri khas dari pendidikan diantaranya aspek sikap, pengetahuan, dan keterampilan. Dengan kata lain, maka bisa disimpulkan juga bahwa mata pelajaran pendidikan jasmani, olahraga, dan kesehatan merupakan mata pelajaran yang sangat penting untuk diajarkan kepada siswa karena dengan demikian akan terwujud pendidikan yang holistik yang mampu menumbuhkan dan mengembangkan segenap potensi siswa. Namun berdasarkan pengamatan penulis, pelaksanaan pembelajaran pendidikan jasmani, olahraga, dan kesehatan dibeberapa sekolah masih belum optimal dilakukan. Salah satu kendala yang sering dijumpai adalah rendahnya minat belajar siswa pada mata pelajaran pendidikan jasmani, olahraga, dan kesehatan. Mereka terlihat kurang serius, kurang antusias, dan terlihat hanya sekedar mengikuti tanpa ada keterlibatan secara emosional didalamnya.

Secara umum minat dapat didefinisikan sebagai suatu perasaan, keinginan, atau kesukaan terhadap setiap kegiatan atau aktivitas pendidikan jasmani. Minat akan timbul karena adanya kebutuhan dan keinginan yang berkenaan dengan dirinya. Penjelasan di atas sejalan dengan yang dikemukakan oleh Hurlock (1990), "bahwa semakin sering minat diekspresikan dalam kegiatan maka semakin kuatlah ia". Berdasarkan pemikiran diatas minat merupakan tingkah laku seseorang secara tidak sengaja akan timbul apabila orang itu penuh kemauan, rasa ketertarikan, keinginan, dan kesenangan. Minat merupakan suatu perhatian khusus terhadap suatu hal tertentu yang tercipta dengan penuh kemauan dan tergantung dari bakat dan lingkungannya itu sendiri. Minat dapat dikatakan sebagai dorongan kuat bagi seseorang untuk melakukan segala sesuatu dalam mewujudkan pencapaian tujuan dan cita-cita yang menjadi keinginannya.

Dalam kegiatan belajar mengajar tentunya prilaku atau tingkah laku seseorang mencakup segala hal yang dilakukan dan dialami oleh setiap orang. Hal ini akan berkaitan dengan hal-hal yang disebut sebagai sifat, bakat, minat dan sikap. Sebab pada dasarnya seseorang yang melakukan sesuatu atau memunculkan prilaku tertentu, berarti ia memperlihatkan sikapnya, menunjukan sifatnya, bakat dan minatnya. Dengan kata lain bahwa prilaku seseorang sebenarnya merupakan perwujudan dari sifat, sikap, minat, bakatnya dan pribadinya walau masih dipengaruhi oleh hal-hal lain. 
Olahraga tradisional menurut (Rhea, 2010) adalah yang dapat " didefinisikan sebagai olahraga kompetitif peristiwa yang melibatkan manusia dalam persaingan dengan manusia atau hewan lain biasanya dalam suatu definisi area yang diatur oleh aturan yang ditetapkan " . permaianan yang dimainkan oleh anakanak dengan alat-alat yang sederhana, tanpa mesin, asalkan anak tersebut sehat, maka ia boleh ikut bermaian. Permaianan tradisional merupakan permaianan yang penuh nilai-nilai dan norma-norma yang luhur yang berguna bagi anak-anak untuk memahami dan mencari keseimbangan dalam tatanan kehidupan sehari-hari.

(Eva I. E, 2014) permainan adalah kegiatan yang disusun sedemikian rupa yang merupakan aktualisasi diri terhadap kegiatan yang disukai, melalui permainan dapat membangun diri, pengenalan, dan juga dapat mengekspresikan diri, dalam proses belajar maka beberapa tujuan belajar dapat tercapai. Sedangkan pendapat (Pertiwi, 2011) aktivitas yang dilakukan (oleh anak) secara spontan, tanpa paksaan, tanpa didesak rasa tanggung jawab atau tujuan tertentu, dapat mendatangkan rasa gembira, dilakukan dalam suasana menyenangkan sebagai cermin kebutuhan untuk memperoleh pengetahuan dan pengalaman baru secara menyenengkan. (Sumarno , 2019) permainan adalah sarana yang dilakukan untuk aktivitas bermain, didalamnya terdapat peraturan serta alat yang sudah difahami bersma dan yang sudah di sepakati oleh anggota yang melakukan aktivitas bermain tersebut.

Permainan tradisional menurut (Prastiwi , 2011) permainan tradisional adalah aktivitas yang dilakukan secara spontan, tanpa paksaan, tanpa didesak oleh rasa tanggung jawab ataupun tujuan tertentu, mendatangkan rasa gembira dalam suasana yang menyenangkan berdasarkan tradisi yang ada dilingkungannya. Permainan tradisional merupakan suatu permainan yang berasal dari daerah masing masing yang kemudian dikembangkan dan dilestarikan menjadi suatu permainan olahraga dan pendidikan jasmani, yang kemudian masuk kedalam kurikulum pembelajaran di setiap sekolah -sekolah baik di tingkat Taman Kanak-kanak ( TK), Sekolah Dasar (SD), Sekolah Menengah Pertama (SMP), dan Sekolah Menengah Atas (SMA). Perkembangan permainan tradisional saat ini cenderung kurang populer, karena permainan tradisional sudah mulai ditinggalkan sehingga kurang digemari dan di minati oleh kalangan remaja karena saat ini banyak olahraga yang bersifat modern sehingga terancam akan punah.

Permainan tadisional bisa dimainkan sendiri, berpasangan, kelompok kecil, kelompok besar, dengan teman sebaya, bahkan dengan orang dewasa. Mereka bermain dengan alat bermaian yang unik yang di buat oleh anak-anak itu sendiri bahkan orang dewasa pun ikut membantu dengan menggunakan alat-alat dari barang bekas, benda-benda atau tumbuhan yang ada di sekitar mereka. Permainan tradisional diantaranya kucing tangkap, hitam-hijau, oray-orayan, bebentengan, jala ikan, lompat tali, egrang, galah asin, gatrik, boy-boyan, sondah, sorodot gaplaok, kucing bola, balap karung. itu semua melibatkan fisik, sosial, emosional, kognitif. Menurut Montessori yang dikutif oleh Nurlan Kusmaedi dalam buku modul permainan tradisional (2010: iii) mengemukakan bahwa:

1. Bermain melibatkan motivasi intrinsik dan spontanitas anak sebagai individu.

2. Bermain aktif melibatkan anak tenggelam dalam dunia mereka sebagai anak. 
3. Bermain sangat lentur, mendorong dari mereka mampu berubah menyesuaikan diri saat bermaian dengan

mengikuti berbagai aturan yang dibuat dengan cara - caranya.

4. Dalam bermain ada sebuah proses yang dilalui anak, bukan hanya perolehan hasil semata.

Berdasarkan paparan diatas, peneliti tertarik untuk memperoleh informasi tentang Pengaruh Permainan Tradisional Terhadap Minat Siswa Pada Pembelajaran Pendidikan Jasmani, Olahraga, dan Kesehatan di SMAN 1 Cikembar Kabupaten Sukabumi.

\section{METODE}

Sugiyono (2007), mengemukakan "Metode penelitian pada dasarnya merupakan cara ilmiah untuk mendapatkan data dengan tujuan dan kegunaan tertentu". Metode yang digunakan dalam penelitian ini adalah metode eksperimen. Dalam hal ini, metode eksperimen yang penulis maksud adalah Quasi Experimental. Metode ini di gunakan atas dasar pertimbangan bahwa sifat penelitian eksperimental yaitu mencobakan sesuatu untuk mengetahui pengaruh atau akibat dari suatu perlakuan atau treatment.

\section{Desain Penelitian}

Desain penelitian merupakan rancangan penelitian yang akan dilaksanakan, desain penelitian yang digunakan dalam penelitian ini adalah One Group Pretes-posttes Design Peneliti memberikan treatment. Berikut merupakan tabel desain penelitian One Group pretest-posttest Design.

Gambar 1 desain penelitian.

\begin{tabular}{|ll|}
\hline T1 & T2 \\
\hline
\end{tabular}

Maksum (2012)

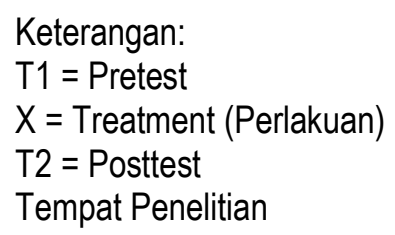

Penulis mengambil lokasi penelitian ini di SMAN 1 Cikembar Kabupaten Sukabumi, Jalan Pelabuhan II KM. 20 Desa/Kecamatan Cikembar.

Menurut Arikunto (2010), populasi yaitu "Keseluruhan subjek penelitian". Populasi adalah wilayah generalisasi yang terdiri atas: objek/subjek yang mempunyai kualitas dan karakteristik tertentu yang ditetapkan oleh peneliti untuk dipelajari dan kemudian ditarik kesimpulannya.

Populasi dalam penelitian ini adalah siswa kelas X MIPA SMAN 1 Cikembar Kab. Sukabumi. Keadaan populasi lebih jelas dapat dilihat pada tabel sebagai berikut: 
Tabel 1 Populasi Penelitian

\begin{tabular}{ccccc}
\hline No & Kelas & Perempuan & Laki-laki & Jumlah \\
\hline 1 & MIPA 1 & 15 & 13 & 28 \\
\hline 2 & MIPA 2 & 11 & 14 & 25 \\
\hline 3 & MIPA 3 & 11 & 17 & 28 \\
\hline 4 & MIPA 4 & 13 & 15 & 28 \\
\hline Jumlah Total & & & 109 \\
\hline
\end{tabular}

Sampel menurut Sugiyono (2007) Sampel adalah bagian dari jumlah dan karakteristik yang dimiliki oleh populasi tersebut. Teknik pengambilan sampel adalah dengan teknik cluster random sampling. Untuk menentukan sampel dalam penelitian ini penulis merujuk pada pendapat Maksum (2012): "Dalam cluster random sampling, yang dipilih bukan individu, melainkan kelompok atau area yang kemudian disebut cluster". Kelas yang dipilih dalam penelitian ini yaitu kelas X MIPA 3 dengan jumlah siswa laki-laki 11 dan siswa perempuan 17 sehingga berjumlah 28 siswa

Instrumen penelitian adalah suatu alat yang digunakan untuk mengukur fenomena alam maupun sosial yang diamati. Secara spesifik, fenomena ini disebut variabel penelitian (Sugyiono, 2009). Sebelum melakukan penelitian, peneliti terlebih dahulu mempersiapkan instrumen penelitian menggunakan skala likert mengacu pada Nurhasan dan Cholil (2017)

Metode analisa data adalah dengan cara yang digunakan adalah mengolah data dari hasil pengumpulan data. Untuk menentukan teknik analisa data harus disesuaikan dengan masalah, desain eksperimen dan jenis data yang diperoleh. Teknik analisa data hasil penelitian ini menggunakan analisa statistika deskriptif, menurut Maksum (2012) menyatakan bahwa, "statistik deskriptif adalah bagian dari statistik yang membahas mengenai penyusunan data ke dalam hipotesis atau penarikan kesimpulan". Adapun yang diujikan seperti uji normalitas, uji homogenitas dan uji hipotesis. Setelah mendapatkan data lalu dimasukkan kedalam SPSS (Statistical Package For The Social Sciemces).

\section{HASIL}

\section{Deskripsi Data}

Setelah melakukan penelitian diperoleh data pretest dan postest minat belajar siswa dalam pembelaajran pendidikan jasmani olahraga dan kesehatan di SMAN 1 Cikembar. Berikut ini peneliti tampilkan ringkasan deskripsi data hasil penelitian:

Tabel 2 Hasil nilai pretest dan postest minat belajar siswa dalam pembelaajran pendidikan jasmani olahraga dan kesehatan di SMAN 1 Cikembar

\begin{tabular}{llll}
\hline Jumlah Sampel 28 & Pretest & Postest & Gain \\
\hline Jumlah & 3090 & 4079 & 989 \\
\hline Rata-rata & 110,35714 & 145,678571 & 35,3214 \\
\hline
\end{tabular}




\begin{tabular}{llll}
\hline Skor tertinggi & 142 & 172 & 87 \\
\hline Skor terendah & 85 & 120 & 3 \\
\hline
\end{tabular}

Dari tabel 2 diperoleh nilai pretest dan posttest untuk tes minat belajar siswa dalam pembelaajran pendidikan jasmani olahraga dan kesehatan di SMAN 1 Cikembar, dengan jumlah sampel sebanyak 28 siswa didapat data pretest dengan jumlah 3090, rata-rata 110,3571, nilai tertinggi 142, dan nilai terendah 85 . Sedangkan untuk nilai posttest dengan jumlah 4079, rata-rata 145,68, nilai tertinggi 172 dan nilai terendah 120. Gain dengan jumlah 989 , rata-rata 35,32 , skor tertinggi 87 , dan skor terendah 3 . Hal ini menunjukan bahwa dengan permainan tradisional memberikan peningkatan terhadap minat belajar siswa pada pembelajaran pendidikan jasmani olahraga dan kesehatan di SMAN 1 Cikembar.

\section{Uji asumsi}

a. Uji normalitas

Adalah sebuah Uji yang dilakukan dengan tujuan untuk menilai sebaran data pada sebuah kelompok data atau variabel, apakah sebaran data tersebut berdistribusi normal ataukah tidak. Uji Normalitas berguna untuk menentukan data yang telah di kumpulkan berdistribusi normal atau diambil dari populasi normal.

Tabel 3 Uji normalitas hasil nilai pretest dan postest minat belajar siswa dalam pembelaajran pendidikan jasmani olahraga dan kesehatan di SMAN 1 Cikembar

\begin{tabular}{lllll}
\hline Data & Sig & & Kesimpulan \\
\cline { 1 - 1 } Pretest & 0,05 & Normal \\
\cline { 1 - 2 } Postest & 0,875 & & Normal \\
\hline
\end{tabular}

Dari data tersebut didapat sig pretest 0,775 dan posttest 0,879 , kriteria pengujian normal Sig $>0,05$ maka data berdistribusi normal. Disimpulkan bahwa data hasil test minat belajar siswa dalam pembelajaran penjas berdistribusi normal.

b. Uji homogenitas

Pengujian mengenai sama tidaknya variansi-variansi dua buah distribusi atau lebih.

Tabel 4 Uji homogenitas hasil nilai pretest dan postest minat belajar siswa dalam pembelaajran pendidikan jasmani olahraga dan kesehatan di SMAN 1 Cikembar

\begin{tabular}{cccc}
\hline Data & Sig & & Kesimpulan \\
\cline { 2 - 2 } $\begin{array}{c}\text { Pretest dan } \\
\text { postest }\end{array}$ & 0,769 & 0,05 & Homogen \\
\hline
\end{tabular}

Dari hasil pengolahan data tersebut, diuji tes homogenitas data pretest dan posttest hasil minat belajar siswa dengan 0,769. Jika sig >0,05 maka disimpulkan bahwa, data tersebut homogen.

\section{Uji hipotesis}

Uji hipotesisi metode pengambilan keputusan yang di dasarkan dari analisis data, menggunakan SPSS paired sample t test. 
Tabel 5 Uji hipotesis hasil nilai pretest dan postest minat belajar siswa dalam pembelaajran pendidikan jasmani olahraga dan kesehatan di SMAN 1 Cikembar

\begin{tabular}{cccc}
\hline Data & Sig & & Kesimpulan \\
$\begin{array}{c}\text { Pretest dan } \\
\text { postest }\end{array}$ & 0,00 & 0,05 & Signifikan \\
\end{tabular}

Dari hasil pengolahan data tersebut, Sig $=0,00<0,005$ data pretest dan posttest hasil minat belajar siswa. Maka dinyatakan bahwa terdapat pengaruh yang signifikan terhadap minat belajar siswa dalam pembelajaran penjas di SMAN 1 Cikembar melalui permainan tradisional.Pembahasan Hasil Penelitian

Dari data di atas berdasarkan hasil penelitian bahwa pembelajaran pemainian tradisional memberikan pengaruh terhadap minat siswa. maka guru diharapkan mampu menjaga minat siswa selama pembelajaran. Uji minat siswa terhadap pembelajaran pendidikan jasmani dapat terlihat dari hasil angket yang diberikan sebelum dan sesudah pembelajaran. Dari hasil perolehan angket terlihat bahwa minat siswa pada awal pembelajaran (pretest) dengan nilai terendah berkisar antara 85 dan tertinggi adalah sebesar 142 , dengan nilai rata-rata sebesar 110,35.

Setelah dilakukan pembelajaran dengan menggunakan pembelajaran tradisional maka terjadi peningkatan minat siswa. Data postest terendah adalah sebesar 120 dan tertinggi adalah sebesar 172 dengan nilai rata-rata 145,67 demikian seluruh siswa bisa dikatakan berminat dalam mengikuti pembelajaran pendidikan jasmani.

Dari treatmen selama penelitian tentang pengaruh permainan tradisional terhadap minat siswa pada pembelajaran pendidikan jasmani, olahraga dan kesehatan menunjukan hasil yang positif dan memiliki hubungan yang signifikan. Penulis memperoleh gambaran yang signifikan tentang hubungan antara permainan tradisional terhadap minat siswa pada pembelajaran pendidikan jasmani dilihat dari berbagai aspek diantaranya: sikap, keinginan, perhatian, ketekunan, dorongan atau motivasi serta penulis memperoleh gambaran yang signifikan tentang hubungan antara permainan tradisional terhadap minat siswa dan pendidikan jasmani

\section{PEMBAHASAN}

Permainan tradisional berpengaruh terhadap minat siswa dalam pembelajaran pendidikan jasmani khususnya di SMAN 1 Cikembar. Dalam hal ini siswa merasa senang, gembira, aktif, inovatif, kreatif dalam melakukan dan melaksanakan tugas Pembelajaran. Karena dalam teori menurut (Kusmaedi. 2010) menyatakan bahwa "Bermain adalah dunia anak". Semakin banyak siswa bergerak, semakin kuatlah ia dalam melakukan segala aktivitas yang dilakukanya. Dalam bermain berbagai pengalaman akan tumbuh dan berkembang karena didalamnya terdapat tiga ranah kognitif, epektif dan psikomotor.Untuk dapat menumbuhkan minat dan siswa dalam mengikuti pembelajaran pendidikan jasmani dibutuhkan inovasi- 
inovasi dari guru dalam menerapkan permainan-permainan yang disukai dan dikuasai oleh siswa, sehingga siswa tidak bosan dan jenuh untuk melaksanakan pembelajaran pendidikan jasmani.

(Kusmaedi, 2010) menyatakan permainan tradisional adalah permainan yang dimainkan oleh anakanak dengan alat-alat yang sederhana, tanpa mesin, asalkan anak tersebut sehat, maka ia bisa ikut bermaian. Selanjutnya (Kusmaedi, 2010) mengemukakan permainan tradisional adalah permainan yang penuh nilai-nilai dan norma-norma luhur yang berguna bagi anak-anak untuk memahami dan mencari keseimbangan dalam tatanan kehidupan.

Berdasarkan teori diatas, guru harus bisa menerapkan permaianan tradisioanl dalam pembelajaran pendidikan jasmani. Guru harus mampu berpikir untuk mengolah permaian tradisional agar bisa diterima di lingkungan dunia pendidikan jasmani dan sesuai dengan kemampuan gerak siswa, sehinggan siswa mampu mengikuti materi yang diajakan guru dan ketika terdapat kesulitan saat pembelajaran. Guru mampu menyelesaikan permasalahan berdasarkan pada pengalaman sesuai dengan kemampuan yang dia miliki yang tercipta ketika dilapangan.

Berdasarkan pernyataan di atas permainan tradisional sangat berguna untuk di ajarkan dilingkungan dunia pendidikan jasmani, karena permaiana tradisional sejalan dengan teori pendidikan jasmani yang di kemukakan oleh (Saputra, 2008), "pendidikan jasmani merupakan pendidikan yang dilakukan melalui aktivitas fisik dan olahraga sebagai media utama untuk mencapai tujuan pendidikan nasional".

\section{SIMPULAN}

Permaian tradisional mampu meningkatkan minat siswa dalam pembelajaran pendidikan jasmani di SMAN 1 Cikembar. Dalam permainan tradisional terdapat berbagai aspek yang menjadi ciri utama diantaranya rasa tanggungjawab, kerjasama, saling menghormati, disiplin, kerja keras, saling menolong. Maka dari itu permainan tradisional sangat menarik untuk di ajarkan di setiap pembelajaran pendidikan jasmani karena dampak dari permainan tradisional akan positif terhadap peningkatan minat siswa. Namun penulis mengajukan untuk lebih kretif dalam menerapkan permainan tradisional karena harus bisa menyesuaikan kondisi yang terjadi di lapangan agar mampu memberikan hasil yang signifikan dalam meningkatkan minat siswa dalam mengikuti pembelajaran pendidikan jasmani.

\section{REFERENSI}

Arikunto, Suharsimi. (2007). Prosedur Penelitian. Jakarta: Rineka Cipta.

J. Rhea, Deborah, ( 2010 ) Personality Trait Differences of Traditional Sport Athletes, Bullriders, and Other Alternative Sport Athletes, TCU Box 297730, Fort Worth, TX 76129, USA

Kusmaedi, Nurlan. (2010). Modul Permainan Tradisional. FPOK UPI. 
Moch Latif1, Faiz Faozi², Rafdlal Saeful Bakhri ${ }^{3}$, Farid Harja4 ${ }^{4}$ Arfin Deri Listiandi5/ PAJU : Physical Activity Journal 1 (1) (2019)

Maksum, Ali. (2012). Metodologi Penelitian. Surabaya: Unesa University.

Nurhasan dan Hasanudin. (2017). Tes dan Pengukuran Pendidikan Keolahragaan. Bandung: UPI.

prastiwi, W., \& S.H Wisnu . (2011). Pengaruh permainan tradisional pada kecerdasan emosi anak. Seminar Nasional mengungkap potensi peserta didik sebagai basis pengembnagn pendidikan karakter ( $p$. 34). Jember: ISBN 978-602-18323-0-1 Unmuh Jember.

Saputra, Yudha. Dkk (2007). Pendidikan Jasmani Dan Olahraga. MKU UPI Bandung.

Sugiyono. (2011). MetodePenelitianPendidikanPendekatanKuantitatif, Kualitatif, Dan R\&D. Bandung: Alfabet 